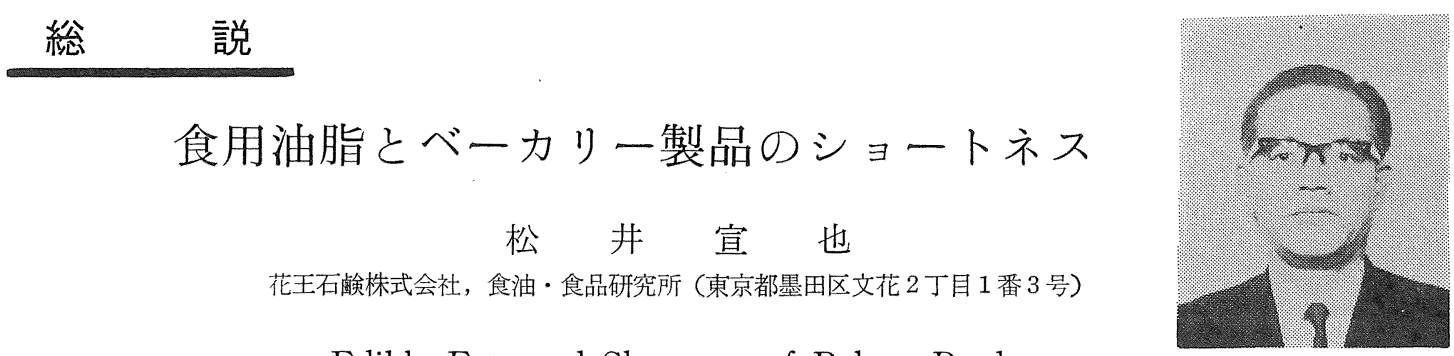

Edible Fats and Shortness of Bakery Products

\title{
Nobuya Matsui
}

Edible Oil and Fat Rasearch Laboratories, Kao Soap Co., Ltd. (1-3, Bunka 2-chōme, Sumidaku, Tokyo)

\section{1 ベーカリー製品のショートネス}

ベーカリー製品のショートネスとは，もろいこと，さ くさくすることを意味し，製菓原料のうちおもに油脂が この性質を与えるので，特にこの目的のために調製され る油脂を, 周知のようにショートニングといい, Bailey ${ }^{1)}$ は豚脂をも含めて, ショートニングェージェントとよん でいる。しかし，油脂類は流動パラフィンなどととも に, すべてショートニングの性質をもち，ただその性状 によって,ショートニング性に差がみられるだけであ る。

現在ではすでに欧米はもとよりわが国においても，特 殊なものは別として, ショートニングの代表的な形態は ほとんど完成し, ベーカリー製品の種類に応じて, それ に適するショートニングを選ぶことができる。表-1 は, ベーカリー製品に応じてショートニングがそなえるべき 特性を整理したものである。ベーカリー用に用いられる マーガリンについても同じことがいえる。

表-1 各種のベーカリー製品に応じて要求される ショートニングの諸性質

\begin{tabular}{|c|c|c|c|c|c|}
\hline ショートニングの性質 & $\mid \begin{array}{l}ク リ ー ミ ミ ~ \\
\text { ソグ性 }\end{array}$ & 可塑性 & ショー゙性 & 乳化性 & 酸 化 \\
\hline ベーカリ一製品の種類 & & & & & \\
\hline パンおよびロール & - & (C) & - & O & - \\
\hline ク ラッカ カ & - & 0 & (a) & - & (C) \\
\hline ケ 一 キ & (C) & 0 & - & (C) & - \\
\hline $\begin{array}{l}\text { ビスケット, クッキ } \\
\text { ー, ウェフォー }\end{array}$ & - & 0 & (C) & - & O \\
\hline パイ クラスト & - & (2) & (2) & - & O \\
\hline $\begin{array}{l}\text { デニシュ, パフペー } \\
\text { ストリー }\end{array}$ & - & (2) & - & - & - \\
\hline
\end{tabular}

注：(）きわめて重要, ○重要,一あまり重要ではない

$\mathrm{Matz}^{2)}$ は, 現在では総称してスナック食品とよばれて いるもののうち, ぱりぱりしたフレーキーなパイや, ビ スケット，クラッカー，朝食用殼物食類をもろい食品 (friable food) として分類し，これらの物性について述
べている。これによれば, ショートネスはとくにこれら の食品に重要な特性であり，その一般構造は，小さく不 規則な断片が，気ホウを介在させるかまたは，種々のテ クスチャーをもつ固体，もしくは可塑性の組織中におい て，どちらかといえばかなりゆるく結合している。たと えばビスケットを例にとり観察すると, まずドー（練り 粉）は不均一であり，その中に脂肪は大低通常の顕微鏡 によりみえる程度の大きさで不連続に分散している。こ れを焼くと，おそらく水一油脂界面においてはじめに形 成される水蒸気と炭酸ガスによる膨脹ガスが，ドーの中 に一杯になる。同時にデンプンのコ（糊）化やタンパク 質の変性凝固が起こり，比較的つよい構造を形づくる が, 油脂はこの間に分散して, 構造の連続性を切断して いる。発生したガスは一部ドーからにげるが，大部分は 不規則な気ホウとなったり，組織中に層をつくりあげ る。製品は一般に熱時には全体が可塑性であるが，冷え るにつれてかたくもろくなる。ビスケットのくだけやす さは, 気ホウの大きさ, 形状, 分布のしかた, 水分, ク ラム（内相）の性質，冷却時に与えられるひずみなどに よる。この際に水分は $5 \%$ 以下であると一般的にもろい 食感があるが，10\% を越えると弾性を示し，しこしこ しはじめる。

もろい食感をもちあじとするベーカリー製品における 油脂のショートニング性の研究はかなり古くからある。 表-1 においてクラッカー，ビスケット，クッキー，パ イクラスト用のショートニングには, 可塑性とショート ニング性がとくに望まれ，さらに保存期閒の長い場合に は，酸化に対する安定性が重要な要求特性となるが，一 般にクリーミング性は比較的非重点の性質である。とく にケーキ用のショートニングの性質と対しょ的である。 一般的には現在では 表-1 のような概念が整理されてい るが,ここにいたる研究の過程や, 詳細にたちいった現 象は複雑である。

1921 に Davis ${ }^{3)}$ はショートメーターを考案し, これ を Bailey (C.H.) ${ }^{4)}$ が 1934 に自動的な装置に改良し 
た。その後, ショートニングの研究はショートニング性 の定量化に刺激されて行なわれ発表されてきた。これは ビスケットやクラッカーの破断抵抗力をはかる装置であ るが，その研究の報告をみると，ベーカリー製品の大規 模な生産における油脂の選択や品質の評価というより， 家庭におけるベーキングの問題として検討されたものが かなり見らけられる。

ベーカリー製品のショートネスに関する研究は, ショ ートメーターを中心にしてすでに行なわれ，一時期をす ぎたように見らけられる。また工業的な問題としてもす でに現在では具体的にはほとんど解決されている。

しかし最近，分子レベルにおいては脂質と小麦粉，と くにグルテンとの関係がかなり詳細に研究され，一方で は食品におけるレオロジー的な性質が種々の手段によっ て研究されようとしている。ベーカリー製品のショート ネスに関する問題は決して新しくはないが，このような 時期にその研究のあとをふりかえるのも有用であるう。

Davis が3)，あらたに提案したショートメーターによ り, シュガークッキーを試験対象にして, 豚脂, 植物油 およびその硬化油のショートニング価を測定し定量的に 表わしてから間もなく, Platt と Fleming ${ }^{5)}$ (1923) は 油脂のショートニング性について，多角的にかつ細部に わたる考察を試みた。この論文の新しい見解は, 油脂の ショートニング性をその可塑性, 潤滑性の面からだけで はなく, 表面現象に関する当時の新しい理論を適用して 考察した点にある。それは Harkins ${ }^{6)}$ (1917) の表面張 力と吸着作用に関する結論および Langmuir ${ }^{7)}$ (1917)の 単分子吸着説との適用であり, 不飽和度の高、油脂ほど ショートニング性の大なる理由を, その吸着作用および 被覆表面の大きい結果であると説明した。他に油脂の粘 度, 表面張力, 融点などをあげているがいずれもおもな 要因ではないとしている。しかし，この論文の新しい見 方である Harkins と Langmuir の理論の適用は, 植物 油に比較して不飽和度の低い豚脂のショートニング性の よいことを例外としなければならず，また数多い種類の グリセリドの混合物である市販の油脂が, 表面現象にお いて純䊉なトリグリセリドのように挙動するかどうかに ついては, Langmuir 自身の指摘もあって保留している。

分子レベルの考察とともに, この論文においてはシュ ガークッキーのドー中の油脂の分散状態を顕微鏡によっ て観察している。この際油脂はスーダン亚によって染め られている。油脂がデンプン粒を薄い被膜でおおってい るが，この膜の厚みはその場所によってさまざまであ り，所によってはかなり大きいかたまりのままで混在し ているところもある。これをやきあげたクッキーにおい ては, 油脂は全体に分散して同じような層状をなしてい ると認めた。また寺田ら ${ }^{8}(1960)$ もソフトビスケットに ついて，代表的な各種の油脂のドーおよびやきあげた製
品中の分散状態を顕微鏡によって調べている。

これによれば，可塑性のよい油脂はドー中に薄層状に 広い範囲に広がり，燒きあげ製品は層状の断面を示して いる。しかしややかたく可塑性の悪い油脂はドー中で不 均一の塊状のままとどまり, このやきあげ製品は破断抵 抗が比較的大きい。これに反して液状油はドー中で油滴 状に分散し，焼きあげ製品の破断抵抗は少ないが多孔質 で mealy (あら粉状) なものとなるとしている。

顕微鏡下に打ける観察と製品の性状との対応はややマ クロな範囲に㧍ける現象である。これに対して分子レベ ルの現象と推定される研究を $1947 に$ Carlin ${ }^{9}$, Broth$\mathrm{er}^{10)}, \mathrm{Olcott}^{11)}$ らが発表している。Carlin によれば, パンをつくる際にショートニングをホモジナイザーで乳 化して加えた場合は，そのままで加えた場合に比べてそ のショートニング性が低下した。この現象を, ショート ニング作用はデンプンやグルテン表面にショートニング が最も大きい表面積, すなわち単分子膜状に広がる際に 発揮されると考察した。乳化して加えるより，ドーの高 速かくはんによってショートニングは単分子状に分散す ると推定している。また Brother, Olcottは, ドー混合 中に油脂とグルテンが結合すると, 混合前にエチルエー テルで $70 \%$ 抽出された油脂が，混合後ではわずか $30 \%$ しか抽出されないこと，さらに混合したドーをデンプン とグルテンに分けると, 結合した油脂はグルテン側に残 ることを認めている。

その後, 製パン性における小麦粉の脂質, 添加油脂の 挙動の重要性が種々の角度より研究され議論されている が，1963 に Baldwin ${ }^{12)} ら$ はぎのような実駼結果を発 表している。製パン法は従来法と連続法, 油脂は小麦粉 脂質と添加油脂について行なわれた。おもに連続製パン 法における各種の油脂および配合油の製パン性について の検討結果が述べられているが，図-1 は小麦粉脂質約 $2 \%$ ，添加脂肪 3\% の場合に，連続法と従来法それぞれ において，ドーおよびパン中の遊離油脂と結合油脂の脂 肪酸組成を比べたものである。石油エーテルにより抽出 されるものを遊離油脂, さらに酸により加水分解して回 収されるものを結合油脂としている。図-1 よりみると， 連続法の パンの方が結合油脂が多く $87 \%$ 亿達してい る。また一般的にリノール酸部の方がより多く結合して いる。さらに Baldwin らは, ミクロベーキングの方法 により，連続製パン中のドーおよび燒成中の油脂の挙動 を顕微鏡観察している。ドー中においては油脂はグルテ ンフィルムにそってより多く集まり，これをベーキング すると，油脂はとけてグルテンフィルムにそって流れ， 小さな空げきを満たし，ベーキング中にガスが逃げるの を防いでいるようにみえる。形成されるリポタンパク質 が，グルテンのネットワークの構造の安定性の保持に有 用のようである。 


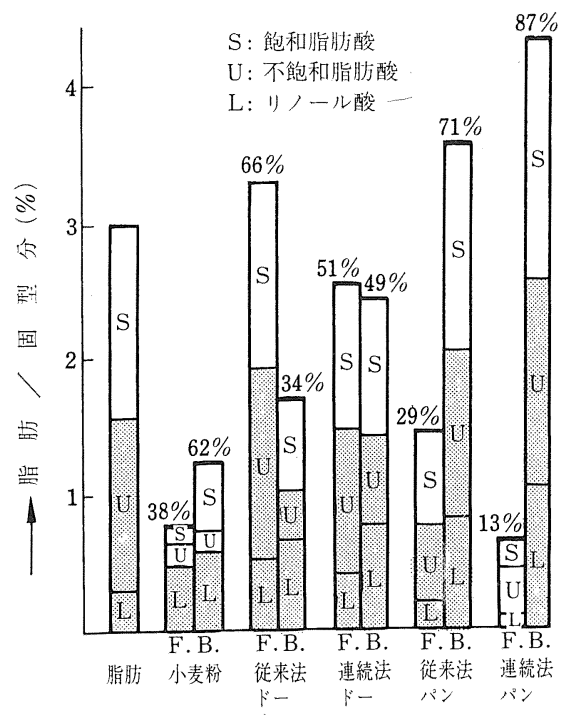

$\mathrm{F}$ : 遊踓脂肪 $\mathrm{B}:$ 結合脂肪

図-1 二つの製パン法におけるドーおよび パン中の脂肪の状態

クッキーについては，Cole $\mathrm{e}^{13)}$ (1960) らが，小麦粉脂 質と焼きあげクッキーの大きさの関係を調べている。水 飽和 $n$-ブチル アルコールにより 小麦粉脂質を抽出して クッキーを焼くと, その直径は未抽出のものに比べて小 さくなる。ふたたび水飽和 $n$-ブチル アルコールに脂質 を分散させて小麦粉にもどし，溶剤を乾燥させてベーキ ングするとクッキーの大きさは回復する。またこのさ い，脂質の含リン区分が重要な役目を果たしている。

脂質とグルテンの微細構造については, Grosskreutz ${ }^{14)}$ (1961) が X 線と電子顕微鏡によって得た結果に基づい て仮説的なモデルを提出している。この報告によれば, 小麦粉からリン脂質を抽出してもグルテンの基本的な小 板状構造はくずれないが，大きな可塑性変形が起こる際 に障害となる。すなわち,グルテン構造中の $2 \sim 5 \%$ の

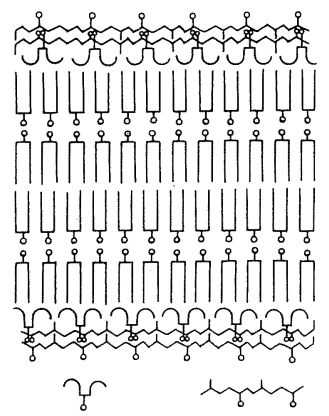

後へ曲がった脂 疎水性側鎖 (人) 肪酸鎖をもつリおよび親水性側 ン脂質分子

鎖（只）をも多 シパク質分子
リポタンパク質が, グ ルテン構造を可塑化し て小麦粉のベーキング 性をたすけているとし ている。図-2 は純粋 なリン脂質とグロビン とが水溶液中に形成さ れたリポタンパク質の 仮定的なモデルであ り, Stoeckenius の所 見から考えられたもの である。また図-3 は Grosskreutz により提 出されているリポタン

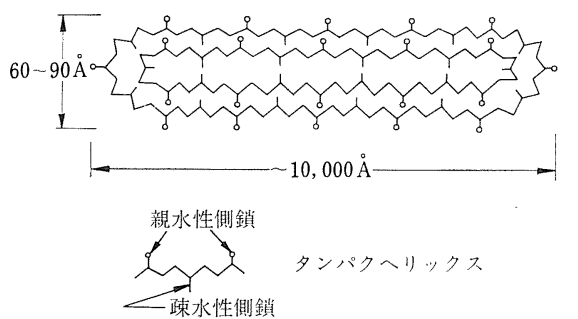

图-3 タンパク 小板の仮定的構造

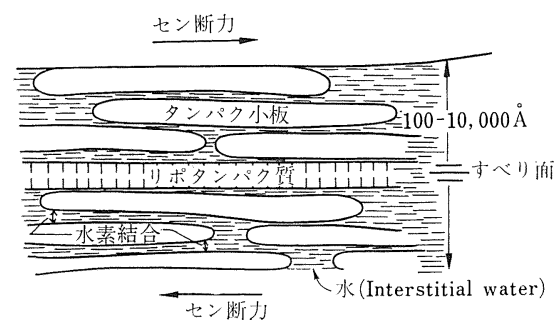

図-4 グルテンシートの仮定的構造

パク質の仮定的な形態を示し，図-4 はグルテン小板構 造について提案されたモデルである。図-4によればグ ルテン小板は水相に掠いて水素結合により結びあってお り，リポタンパク質からなると考えられる弾性小板が他 のグルテン小板に水素または塩類似結合 (saltlike linkage）をしている。この結合はこの図におけるリポタン パク質層内のリン脂質の二分子層間の凝似結合より強い ので,グルテンの構造にセン断力がかかるとき, リポタ ンパク質層がスリップして，構造全体は破壊しないで変 形しうるとしている。Chapman ${ }^{15)}$ (1969) が最近述べて いるように，一般的にリポタンパク質の構造は複雑であ り，過度に簡易化して考えることは危険であろらが， Grosskreutz のモデルは，ベーキングにおける脂質ひい ては油脂とタンパク質との関係を考えてゆくうえに有用 であろう。

Glass $^{16)}$ (1960) はベーキング中における脂質の役割に ついて総括的な考察を行なっているが，脂質とタンパク 質との結合方式を考える一つのてがかりとして, Schle$\operatorname{rud}^{17)}(1957)$ の研究結果を引用している。すなわち, 脂 肪酸のメチルエステルが, そのヨウ素価の高いものほど グルテンに結合する度合が強い。これはすでに述べた Baldwin らの結果の 1 部とも一致する傾向であるが, Glass はトリグリセリドについて, Schulerud と同じよ うな研究をする必要があろらといっている。

Glass はまた, 荷電部分のないトリグリセリドについ ては,リポタンパク質の脂質部分に固溶体を形成してい るのではないかという説をたてている。

以上のように, Platt および Fleming が, ベーキン グ用の油脂において，その不飽和度が分子レベルの現象 に重要な要因であることを指摘して以来, 油脂はデンプ

図-2リポタンパク質の構造 
ンよりグルテンに強く結合し，しかも不飽和度の高いも のほど結合力が強いことが実証されはじめている。

しかし，同じ報文において，ショートニング性を支配 するのは不飽和度だけではなく, 油脂の可塑性, 潤滑性 であることも指摘されており，顕微鏡観察では，ドー中 の油脂の分散は, その形がかなり大きいことが認められ ている。

ショートニングがベーカリー製品の工程, 品質の上に 果たす役割は数多くあるが，その代表的な一つであるシ ョートネスを与える機構を考えてゆくうえに, 分子レベ ルにおける現象を適確に解明する必要性とともに, 数 $\mu$ 〜 $1 \mathrm{~mm}$ 程度にわたる範囲の現象をさらに調べる必要が あると思う。表-2 はベーカリー製品中の種々の物質の 大きさの範囲を整理したものであるが，広、範囲にわた る現象の複合されたものとしてとらえること，またどの 大きさの現象が支配的であるかなどの配慮が必要であ る。表中のソフトビスケットの食感の比較は, 市販のソ フトビスケットを細粉して節分し, 各区分について官能 テストした結果である。

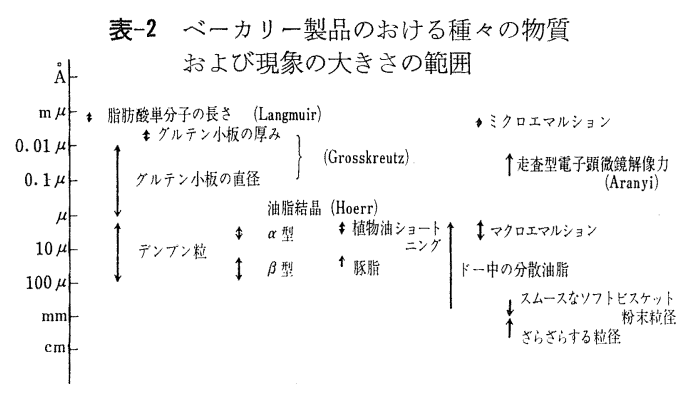

なお, Aranyi ${ }^{8)}$ (1968) は小麦粉およびそのドーを, 走査型電子顕微鏡によって比べ，この方法の可能性につ いて報告している。この際の解像度は通常 $500 \AA$ より よく, よい条件下では $200 \AA$ 程度まで可能であると述 べている。

\section{2 ベーカリー製品のショートネスの測定法}

1921, Davis ${ }^{3)}$ はショートメーターと名づけたベーカ リー製品の破砕試験機を発表した。これはクッキーやク ラッカー, ビスケット, パイなどのもろいベーカリー製 品のショートネス, すなわちもろさを定量的に測定しよ うとするもので，原型はセメントの試験機である。これ をベーカリー製品むきに改造して，その破断抵抗力 (breaking strength) と粉砕抵抗力 (crushing strength) をはかる 2 種の測定機が提案されている。 breaking strength を以下は破断力とよぶことにするが, これは 2 本 の平行なレールの上に試験片を置き, これを, レールに 平行な上部からのバーで押して折る。これにかける荷重 は, バーの上部に備えた容器に散弾を徐々に加えること により, 試験片が折れたときの荷重を測定值とする。負
荷の工夫は，バーを支える腕の上をおもりをすべらせる ことによる場合も示されている。30 回の繰返しによっ てデータをとる。また粉砕力をはかるのには, 試験片を 平板の上に置き，これを上方より小さい円板によって押 して砕けたときの荷重をみる。負荷のかけ方は破断力の 場合と同じである。この際破断力をポンドで表わし，シ ュガークッキーを刘象にして各種の油脂のショートニン グ性を測定したところ, 豚脂がもっともよかったのでこ の值を標準 $A$ ポンドとし, 実験油脂の測定值を $B$ ポンド とした際にショートニング価をつぎのように表わした。

$$
\frac{A}{B} \times 100: B \text { 実験油脂のショートニング価 }
$$

1934, Bailey (C.H.) $)^{4)}$ は, Davis の破断力試験機を 改良して自動的にした。図-5 はよく知られている Bailey 式のショートメーターである。これは米国殼物協会 (AACC) のまとめた実験室試験法としてのせられてい るが，その操作法は，試験片をRの上におき，モーター Mをまわして，コードCを $1 \mathrm{~min} 12 \mathrm{~cm}$ の速さでひき， Aにおされて試験片がわれたときの荷重を, はかりBの 指針によって読む。このときの指示を $\mathrm{g}$ でよみとりその ままショートニング価 (shortening value) とする。測 定を正しくするために，試料調製のベーキングは少なく とも 2 回，できれば 3 回行ない，測定には 20 個の試験 片を用いる。この際, チェッキングによる不規則な試料 がはいらないかどらか注意を要する。20 回繰返しの測 定誤差は，平蚐值の $2.41 \%$ であるとしている。

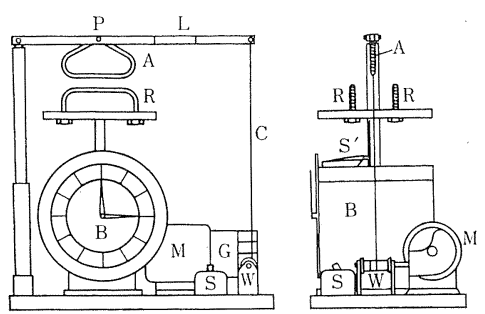

図-5 ショートメーター

この方法はショートニング価測定の標準法のように最 近まで研究者によって用いられている。しかし，米国殼 物協会の実験室試験法の第 7 版 (1962) からは削除され ている。このほか, Coppock と Conford ${ }^{19)} は$,クッキ 一を一組のナイフエッジの上に置き，これをたたくよう にして割り，それが破断するまでに吸収されるエネルギ 一を記録する方法を考案している。

類似したものとして，クリームパフの皮のもろさを小 林, 竹林 ${ }^{20}$ (1968) らがカードメーターにより測ってい る。これはパフの試験片を, $200 \mathrm{~g}$ 荷重をかけた $3 \mathrm{~mm}$ 直径の感圧軸で押し, 貫通するときの読みをとる方法で ある。 
ショートニング価の表現は，実験者によってまちまち である。既述のように Davis ${ }^{3)}$ は, その実験シリーズの 最もよい值を 100 として, これより劣るものはその測 定值との比により，70 あるいは 80 のように表わす。一 方 Bailey (C.H.) は破断力の測定值そのものを $\mathrm{g}$ で表 わす。また Fisher ${ }^{21)}$ (1934) は, ショートニング当量 (shortening equivalent) といら用語によって，たとえ ば，ショートニング值が豚脂が 100 , 硬化綿実油が 70 のとき, その効果の当量は豚脂 70 , 硬化綿実油 100 で あるといら用い方をしている。

破断力を厳密に示すべきならば，破断断面の寸法と， 支点距離, 必要破断力より抗折力を算出して $\mathrm{g} / \mathrm{cm}^{2}$ の 単位で表わすべきであろうが, ベーカリー製品の試験片 の大きさを厳密につくりあげることは, かなり困難であ り，ここまでの必要はないであろう。

Harvey $^{22)}$ (1937) および Ottaway ${ }^{23)}$ (1958) は，ショ ートニング価, 破断力と官能的なショートネスすなわち もろさないしやわらかさ (tenderness) の評価が一致し ない場合があることを示して，破断試験機による破断力 の解釈に注意を促している。

これに対して Mathews ${ }^{24)}$ (1963) はペーストリーの破 断力と官能的なテストの結果がよくその傾向を一致する ことを示した。Mathew は Bailey (C.H.) のショート メーターにより破断力を測り，この数值と，官能的なも ろさの評価とを比べた。口あたりのやわらかさ（tenderness) のスコアとしては，もろく砕けやすい (crumbly) を7とし，きわめてかたくこわれにくい（very tough or firm)を 1 として，7段階を選んでいる。

機械的に測定した破断力と,ショートネスの官能的な 評価の関係は，その值の広い範囲では相関するである う。しかし，口中における食感の微妙な点を問題にする 場合，機械的な測定值がこれを表現するとはいいきれな い。Mathews の場合，かなり広、範囲の相関をいって いるのであり, Harvey および Ottaway の場合, 特殊 で微妙なシ好性にまでたちいって評価しているためであ る。

したがってショートネスの機械的な測定は, 条件のか なり広い範囲の変化による実験結果を示すのには定量的 で便利であるが，実際商品の微妙な品質の評価炕，尺 度としてはあらすぎるといえる。

口中の食感までを含めて評価するとすれば，むしろ粉 䂺力のテスターの方がよいのではないかと思うが Davis の方式ではできない。われわれはかつて，ボールミル中 でソフトビスケットを砕き，これをふるい分けして粒度 分布と，官能的なショートネスの対応を比べたが，かな りよい結果を示した。しかし，ボールミル中で再ケーキ ングし均一にこわれにく、久点が認められた。

類似した方法では，松元 ${ }^{23)}(1958)$ がビスケットをジ

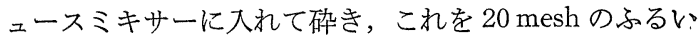
で通し, 通過分の全体に対する重量比でショートネスを 測っている。

$\mathrm{Matz}^{2}$ ) の案としては，もろい食品 (friable food) を シリンダー状の容器に入れ，一定の速度の力でこれを押 し砕き, この粒度分布を比べる方法である。この際, 粉 研に必要な力の変化を記録することを勧めている。この 方法による評価が食感を示す指標になるであるうという 意見である。

松元 ${ }^{25}$ は上記の実験の際, ビスケットの吸水速度を比 べているが，これはショートネス評価の際の食感に関し てかなり重要な要因であり，ショートネスはよいが，口 中でぼそぼそとしてシ好評価が劣る場合の解析の手がか りになると思う。

\section{3 油脂とベーカリー製品のショートネス との関係}

ベーカリー製品とくにもろいベーカリー製品のショー トネスを支配する因子については，Lowe ${ }^{26)}(1955)$ がそ の著書において総説しているが，とくに油脂に関して は, その使用量, 使用温度, 化学的性状, 物理的性状, 使用方法などによってかなり支配される。

使用方法のショートネスに及ぼす影響については， Lowe ${ }^{26)}$ が Bernds(1937) の実験結果を紹介している。 これは油脂と小麦粉との混合時閒, ベーキング温度, 水 を添加後の混合時間, ドーの熟成時間, 焼成後の放置時 間などについてである。竹林 ${ }^{27)}$ もフトビスケットの製 造上の種々の条件が，製品の各種性状に及ぼす影響を詳 細に検討しているが，図-6 はソフトビスケットの主要 原料の使用量が，ビスケットのショートネスに及ぼす結 果を示したものである。砂糖の量がふえる著しく破断力

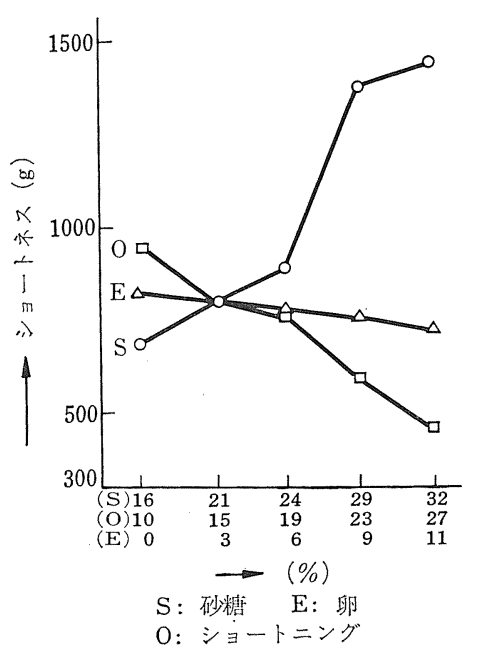

图-6 砂糖, ショートニング, 卵の添加 によるショートネスの相異 が増大するが， ショートニング がふえると低下 する。

$\operatorname{Davis}^{3}$ (1921) はショートメー ターの提案を初 めて行ならとと もに：シュガー クッキーについ て, 4 種の豚脂, 硬化綿実油, バ ター,ヤシ油, 大豆油などの植 物液体油を使用 した際の破断力 を測定した。こ 
のとき，豚脂がもっともよい結果を示したので，これを 基準のショートニング価 100 として，他の油脂の相対的 なショートニング価を求めた。こののちショートメータ 一による定量的な評価法を用いて, 数多い研究が行なわ 礼た。

Denton おちよび Lowe ${ }^{26)}$ (1924) は各種のペーストリー について、、ろいろな油脂の破断力および粉确力に及ぼ す影響を比べた。表-3 はこの結果を示す。破断力につ いてみると, 綿実油, トウモロコシ油, 鵎油または脂肪 が最もよい群に属し, ついで二級品豚脂, バター脂, 即 席乳化の綿実油などがよい。鉱油の類も実験に加えられ ており，結果はよくないが，かなりのショートニング効 果をもっていることがわかる。

表-3 標準条件下でっくられた各種のペーストリーの 破断㧍よび粉砕力 (数值は 48 テストの平均), 混合温度 $80^{\circ} \mathrm{F}$

\begin{tabular}{|c|c|c|c|}
\hline 油 脂 の 種 類 & $\begin{array}{l}\text { 融点 } \\
\left({ }^{\circ} \mathrm{C}\right)\end{array}$ & $\left|\begin{array}{c}\text { 破断力 } \\
(\mathrm{g})\end{array}\right|$ & $\begin{array}{l}\text { 紛砕力 } \\
(\mathrm{g})\end{array}$ \\
\hline パフ・ペーストリー・ショートニング & 61.0 & 612 & 1380 \\
\hline ヤシ油マーガリン & 28.4 & 644 & 1096 \\
\hline $\begin{array}{l}\text { パフ・ペーストリー・ショートニング } \\
\text { (水分なし) }\end{array}$ & - & 592 & 1000 \\
\hline$\therefore$ 夕 $-($ I $)$ & 34.7 & 530 & 902 \\
\hline 夕 $\quad-$ (II) & - & 525 & 802 \\
\hline 油 & - & 402 & 680 \\
\hline 鉱物油（精製油） & - & 418 & 635 \\
\hline ヤシ油マーガリン（水分なし） & - & 340 & 554 \\
\hline ヤ シ 油 & - & 333 & 588 \\
\hline 市販ヤシ 油 & 19.5 & 334 & 537 \\
\hline 豚 脂 (A) (II) & 44.6 & 350 & 532 \\
\hline (I) & - & 344 & 477 \\
\hline 豚 脂 $(\mathrm{L})(\mathrm{I})$ & 40.6 & 327 & 487 \\
\hline (III) & - & 276 & 527 \\
\hline 水添綿実油 & - & 317 & 506 \\
\hline 脂 (B) & 45.4 & 316 & 466 \\
\hline 綿実油（水とのエマルション） & - & 266 & 528 \\
\hline 豚 脂 $(\mathrm{S})$ & 41.4 & 261 & 398 \\
\hline バター（水分なし，カード除去） & - & 268 & 387 \\
\hline 綿 実 油 & - & 249 & 399 \\
\hline トウモロコシ油 & - & 240 & 399 \\
\hline 鶏の油または脂 & - & 233 & 375 \\
\hline
\end{tabular}

Platt および Fleming ${ }^{5)}$ (1924), Fisher ${ }^{19), 25)}$ (1933， 1934）らの結果も綿実油, 豚脂がよく，とくに豚脂はす ぐれた值を示している。

油脂のショートニング性と, その物理的, 化学的性質 との関係については, すでにその一部を 1 において述 べたが, Platt および Fleming ${ }^{5)}$ は, 可塑性, 油脂の不 飽和度, 潤滑性を重要な要因とし, その他, 粘度, 表面 張力, 融点などをあげている。さらに Fisher ${ }^{25)}$ は, 油 脂の凝固点 (congeal point) が重要なめやすになると
した。これが低い油脂ほどショートニング性が良好であ るとした。

しかし, Lowe ${ }^{26)}(1938)$ らは，一般的には油脂の不飽 和度がそのショートニング性を支配するといえるが，こ れだけで現象のすべてを説明することはできないとして いる。その理由は，油脂の性状が，実際は広、範囲にわ たって変化していることに帰している。

一方ほとんど同時期に, Harvey ${ }^{22)}$ (1937) はプレーン ペーストリーについて実験し, 従来の各種の見解をふり かえり，いくつかの重要な所見を発表している。この論 文が発表された時期は，米国の市場に製菓性のよいショ ートニングが市販されはじめたころにあたっていたよう であり，硬化綿実油を主体にした配合ショートニング は，従来もっともよいとされている豚脂に比べて破断力 もおとらず，食感，風味とも総合的にすぐれていること を実証した。これと同時にショートメーターによって測 られる破断力と食感によって比較したショートネスとを 区別し，前者の評価法のみによることに批判的である。

表-4 ステアリソ添加豚脂による破断力 (g) の相対值

\begin{tabular}{c|c|c|c}
\hline 豚 脂 (\%) & ステアリン $\%$ 破断力 $(\mathrm{g})$ & 比較值 $(\%)$ \\
\hline 100 & 0 & 139 & 100.0 \\
99 & $\mathrm{~V}, 1$ & 147 & 105.7 \\
98 & $\mathrm{~V}, 2$ & 146 & 105.1 \\
95 & $\mathrm{~V}, 5$ & 171 & 123.0 \\
90 & $\mathrm{~V}, 10$ & 223 & 160.4 \\
99 & $\mathrm{~L}, 1$ & 142 & 102.1 \\
98 & $\mathrm{~L}, 2$ & 148 & 106.5 \\
95 & $\mathrm{~L}, 5$ & 166 & 119.3 \\
90 & $\mathrm{~L}, 10$ & 217 & 156.0 \\
\hline
\end{tabular}

ステアリン $[\mathrm{V}:$ 極度硬化綿実油, $\mathrm{L}$ ：極度硬化豚脂 $]$

表-4 はこの結果の一つであるが，豚脂を主体にして， ヨウ素価 8.6 の硬化綿実油とヨウ素価 3.5 の硬化豚脂 を 1 10\% の水準で加えた系列の実験より，極度硬化 油の添加量の多い配合油ほど, すなわちチョウ度のかた いものほど破断力が大きい結果を得た。Harvey はこの 結果に従い，可塑性がもっとも重要な支配要因であると した。しかし，配合油の可塑性を表わす性状は測られて いない。

また Harvey は，ケーキを焼く際に，豚脂は著しくそ の性能がおとり，硬化綿実油の配合ショートニングがす ぐれていることを示した。しかし，現在では豚脂のケー キに対する久点は，エステル交換によって改善されてい る1)。

中沢ら ${ }^{28)}(1958)$ は，ソフトビスケットの配合によっ て, 各種の油脂およびその硬化油, 配合油のショートネ スに及ぼす影響を広く調べた。その結果の 1 部を表-5 に示した。なお供試料のチョウ度をミク口針入度によっ て表わし, 結果の考察の一助としている。これを図-7 
忆示した。

たとえば，試料 3，4，7 とを比べて 可塑性のよいも のほどショートニング価がよいとしている。

寺田ら ${ }^{8)}$ の検討した結果についてはすでに 1 亿おいて 述べたが, ショートニングのチョウ度は,ミクロ針入度, ASTM のコーンペネトロメーターで測定した。ビスケ ットの破断力と油脂のチョウ度その他の性状との関係に ついての判断は複雑であるとしている。

表-5 可塑性とショートニング性

\begin{tabular}{|c|c|c|c|c|c|c|c|c|}
\hline 区 & 種 & $\begin{array}{l}\mathrm{mp} \\
\left({ }^{\circ} \mathrm{C}\right)\end{array}$ & I.V. & S.V. & $\begin{array}{l}シ ョ- \\
ト=ン \\
ク ゙ \text { 価 }\end{array}$ & $\mid$\begin{tabular}{|} 
標準 \\
偏羞美
\end{tabular} & $\begin{array}{l}\text { サン } \\
\text { プル } \\
\text { 数 }\end{array}$ & $\begin{array}{l}\text { 変動 } \\
\text { 系数 } \\
\end{array}$ \\
\hline 1 & シ (原油) & 24.0 & 8.6 & 251.5 & 127.9 & 22.1 & 50 & .172 \\
\hline 2 & "（硬化油） & 7.3 & 4.0 & 55.4 & 34.8 & 22.3 & 49 & 0.145 \\
\hline 3 & "（硬化油） & 3 & 0.4 & 253.0 & 155.2 & 19.5 & 48 & 0.14 \\
\hline 4 & $\begin{array}{r}\text { マーガリン ソ } \\
\text { (綿実) }\end{array}$ & 35.3 & 67.6 & 196.7 & 140.2 & 14.5 & 50 & 0.104 \\
\hline 5 & $\begin{array}{l}\text { ショョート } \\
\text { グ }\end{array}$ & 44.0 & 74.7 & 190.8 & 26.2 & 21.6 & 50 & 0.171 \\
\hline 6 & $\begin{array}{l}\text { ジョートニン } \\
\text { グ (ナタネ) }\end{array}$ & 39.4 & 66.6 & 174.5 & 123.0 & 18.3 & 50 & 0.149 \\
\hline 7 & グ(牛脂主体) & 37.4 & 69.0 & 193.4 & 119.5 & 17.8 & 44 & 0.149 \\
\hline
\end{tabular}

Ottaway ${ }^{21)} ら$ (1958) はケーキおよびビスケットにつ いて，油脂の影響を調べているが，ビスケットについて は，ヤシ油および硬化パーム核油を主体にした配合油を 用いて，そのショートニング作用を調べた。ほかに三種 の市販ショートニングを比較した。一般的にショートニ ングとしては性能のよくないといわれているラウリン系 の油脂配合が多い例なので 表-6 にその配合，デイラト メーターによる固体脂量, ビスケットの評価をあげた。

Ottaway は油脂の性状，たとえば融解の形式や範囲 と,ビスケットの大きさ, 破断力との関係はほとんどな いという。官能的に比べたショートネスと破断力とは， 相関がない。

しかし，破断力の数值は単位が示されていないが，数 值は少ないほど研けやすいとすれば, ラウリン系の油脂

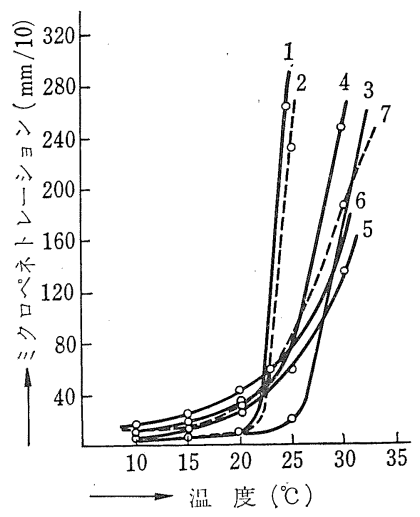

図-7 試料油のミクロペネト レーション
でも低い数值を示 している。しかし 官能的なショート ネスの評価はよい とはいえない。英 国におけるビスケ ットには，ラウリ ン系の油脂の使用 が多い。

油脂のビスケッ

トをはじめとする もろいベーカリー 製品におけるショ ートネスに関係す る要因のうち, 可

塑性が重要な要因であることは, 従来の研究者により述 べられてきたが, 油脂の可塑性について, 特に細かくふ れているものはない。これについては, Bailey ${ }^{1)}$ がその 著書においてとくに詳しく論じており，一般のベーカリ 一製品においては，ドーまたはバッター（生種）中で, 可塑性脂肪は薄膜状に広く展延するので, 液滴状になる 液体油より広い表面で潤滑性が発揮されて, ショートニ ングの効果をあげるとしている。ケーキにおいては，シ ョートニングのクリーミング性が，ケーキのふくらみに 影響がある。

油脂の可塑性は，展延性について官能的に比べた場 合，降伏值としては $100 \sim 1500 \mathrm{~g} / \mathrm{cm}^{2}$ の範囲 ${ }^{29}$ にある。 またミク口針入度の数值ではほぼ $40 \sim 200 \mathrm{~mm} / 10$ の閒 にある。今村, 新谷 ${ }^{30)}$ (1969) らがテーブルマーガリン の展延性について調べた結果では，固体脂指数 10〜30 の範囲がほぼ良好である。

しかし, 油脂のチョウ度は, 温度による固体脂の変 化，結晶型などによって変わり，またかくはんにより結 晶組織が破壞されて一般にチキソトロピックな挙動を示 し，ベーカリー製品の工程中の油脂の変化は上記のよう

表-6 各種の配合油の固体脂量とビスケット応用結果 $\left(70^{\circ} \mathrm{F}\right.$ において混合)

\begin{tabular}{|c|c|c|c|c|c|c|c|c|c|c|c|c|c|c|}
\hline \multirow{2}{*}{ 油脂の種 類 } & \multirow{2}{*}{ 落落花生泊 } & \multirow{2}{*}{ 硬 化 } & \multirow{2}{*}{ ヤシ油 } & \multirow{2}{*}{ 落花生油 } & \multicolumn{8}{|c|}{ 固 体 脂 $\%\left({ }^{\circ} \mathrm{F}\right)$} & \multirow{2}{*}{$\left.\mid \begin{array}{c}\text { 破断力 } \\
\text { (平均) } \\
\left(\begin{array}{ll}\text { 意 } \\
\text { 敩 }\end{array}\right. \\
\text { 位 }\end{array}\right)$} & \multirow{2}{*}{ 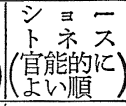 } \\
\hline & & & & & 50 & 60 & 70 & 80 & 90 & 100 & 110 & 120 & & \\
\hline オレオオイル & & & & & 59.1 & 55.4 & 50.4 & 42.9 & 34.8 & 26.5 & 16.8 & 3.4 & 16.4 & 3 \\
\hline 䀠 脂 & & & & & 37.8 & 35.3 & 32.9 & 26.7 & 11.8 & 8.2 & 4.0 & - & 13.2 & 1 \\
\hline 市販コンパウンド & & & & & 32.5 & 28.5 & 25.6 & 21.2 & 17.3 & 9.0 & 4.0 & - & 13.5 & 2 \\
\hline 配 合 1 & 32 & - & 60 & 8 & 38.1 & 27.5 & 5.4 & 0.1 & $\cdot-$ & - & 一 & - & 13.8 & 4 \\
\hline 2 & 24 & - & 60 & 16 & 35.1 & 24.2 & 3.0 & 0.3 & - & - & - & - & 14.9 & 4 \\
\hline $3\left(70^{\circ} \mathrm{F}\right.$ で液状) & 16 & - & 60 & 24 & 31.6 & 21.7 & 1.9 & 0.2 & - & - & - & - & 15.5 & 5 \\
\hline $4\left(70^{\circ} \mathrm{F}\right.$ で液状) & 8 & - & 60 & 32 & 29.0 & 20.8 & 3.0 & 0.3 & - & - & - & - & 9.2 & 5 \\
\hline 5 & - & 60 & 32 & 8 & & & & & & & & & 10.7 & 4 \\
\hline 6 & - & 60 & 24 & 16 & & & & & & & & & 10.8 & 4 \\
\hline 7 & - & 60 & 16 & 24 & & & & & & & & & 10.6 & 4 \\
\hline 8 & - & 60 & 8 & 32 & & & & & & & & & 10.2 & 4 \\
\hline
\end{tabular}


な,かなり変形速度の遅い範囲でとられた結果とはかな り異なると思われる。

油脂のかくはんーワーキングについては，S S ltoft $^{31)}$ が 理論的に論じ, Loska ${ }^{32)}$ (1957) はグリースワーカーによ って時閒経過によるワーキング抵抗の変化を調べてい る。ショートニングは温度およびワーキングによるチョ ウ度変化が少ないことが理想とされるが，これらの検討 とベーカリー製品のショートネスとの関連はまだ適確に 検討されていない。

Mathews ${ }^{24)}$ (1963) はトウモロコシ油, 綿害油, 大豆 油, 豚脂および硬化植物油 I (I.V. 70, mp 42 44)， II (I.V. 88, mp 40 44) の 5 種の油脂のベーキング性を, ペーストリー, 即席パン (quick bread)*1 について調ベ ている。添加水準は 5 段階にして, 油脂の添加量に応じ て，小麦粉に対する水分量をドーのかたさをめやすにし て調節している。主な配合は小麦粉, 油脂, 水分のみで, 即席パンの場合にはふくらし粉を用いる。家庭用の電動 ミキサーで混合するが，固体脂の場合にはそのまま投入 し，液体油の場合は水にまぜて乳化させて投入する。ペ ーストリー, 即席パンとも, 混合法は同じである。形状 はペーストリーの場合には $3 / 32 \times 1 \frac{3}{8} \times 2 \times 2 \frac{1}{4}$ (in) の矩形 平板, 即席パンの場合には愿み $1 / 2$ in, 直径 2 in の円 形に切る。これを焼きあげたものを, ペーストリーの場 合には Bailey (C.H.) のショートメーターによって破 断力を測り, 舌ざわりのやわらかさ (tenderness), フレ 一キーネス, 風味を官能的に評点法で調べる。また即席 パンについては，その上面表皮のセン断応力をWarnerBratzler shear machine*2により, 製品全体のセン断応 力は Kramer shear press*3 で調べ，そのシ好評価を, 表 皮およびクラムの舌ざわりのやわらかさ (tenderness), および風味について行なう。図-8 および図-9 はその結 果の一部を示したものである。これらの機械的測定值に ついて考察すると, 使用油脂のショートニング性能は, 油脂の使用水準, 対象のベーカリー製品の種類によって かなり異なることが明らかである。 Mathews は，たと えばペーストリーに拉いては 41\%, 即席パンでは $25 \%$ の油脂添加水準が，油脂のベーキング性の比較によいと いっているが，表-7 はそれ ぞれの場合によい結果を示

*1 原報では, らくらし粉ビスケット (baking powder biscuit）といっているが, 油脂の多いパソのようなベーカリ 一製品で, 米国においてよくつくられる。ここでは報文中 の他の用語との混乱を避けるために, 即席パンとよぶこと にした。

*2 料理した肉類の柔軟性をはかる目的の測定機であるが，詳 細な構造は明らかでない。G.K. Electric Mfg. Co. 製。

*3 各種の食品のテクスチャーを測定する目的のもので, 試料 を支持して上方より薄い金属板を垂直に押しこみ，その応 力の変化の経過を自記する。セン断用の金属板の種類が 2〜3 種あるが, 本報ではいずれを用いたか明らかでない。 Food Technology Corp. 製。

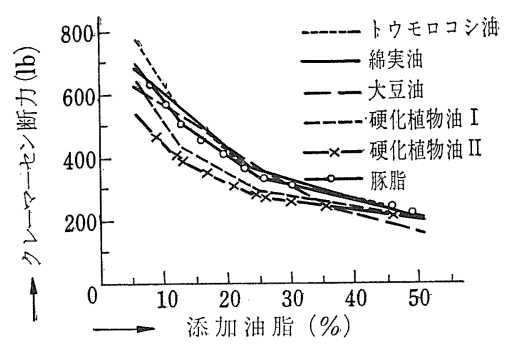

図-8 ペーストリーの破断力に及ぼす添加油脂の影響

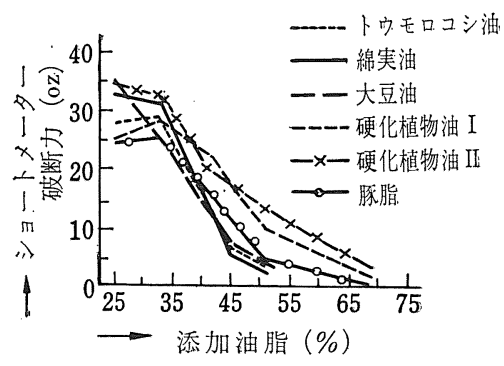

図-9 即席パソ (baking-powder biscuits) のセン断力に 及ぼす添加油脂の影響

表-7

\begin{tabular}{|c|c|}
\hline $\begin{array}{l}\text { ペーストリー } \\
\text { 油脂 } 41 \%\end{array}$ & $\begin{array}{c}\text { 即 席 パン } \\
\text { 油脂 } 25 \%\end{array}$ \\
\hline $\begin{array}{l}\text { トウモロコシ油, 大豆油, } \\
\text { 綿実油 }\end{array}$ & 硬化植物油 II \\
\hline 豚脂 & 硬化植物油 I \\
\hline 硬化植物油 II & 豚脂 \\
\hline 硬化植物油 I & $\begin{array}{l}\text { 綿実油, トウモロコシ油, } \\
\text { 大豆油 }\end{array}$ \\
\hline
\end{tabular}

\section{した油脂の順位である。}

成分比は異なるが，成分の種類のほとんど同じドーに おいて，以上のような点がみられるとともに，油脂の添 加水準によって順位が変化することも，図-8, 図-9 にみ られる。

これらの結果より, Mathews は, ペーストリーの場 合は比重の大なる油脂がよく, 即席パンの場合にはこの 逆であると考えているが，この実験範囲の現象には対応 するにしても，理由が不明りょうである。その他，油脂 の結晶型および油滴の大きさ, 可塑性なども要因として 考えられるといっている。Mathews の実験は, 油脂添 加量が広くとられていること, 成分の種類の近似する配 合において，油分一水分比の異なる系を選び，比較する 特性值の見かけは異なるにしても, 油脂のショートニン グ性が，その場合によって異なる結果を示した点に意味 と示唆があると思う。

以上をふりかえると, Platt と Fleming が 1923 に基 本的な考察を試みて以来, 各種の検討が行なわれ，新し 
、知見も得られている。

一般的には，油脂のいかなる特性がショートネスの支 配因子であるかの研究が試みられ，おもに可塑性が重要 なことが認められている。しかしこの因子のみによって 説明しょうとしてもなお問題は残る。

また一方では分子レベルの現象の研究が，おもに脂質 とグルテンとの関係の解明に注がれている。今後もこの 分野の研究は, 複雑な現象を対象にして, 新しい手段を とりいれながら進められるであろら。

従来の研究抒よび Mathews らの方法の示唆に基づい て考えると，すでに 1 において述べたように，まずべ 一カリー各工程における支配的な現象は，それぞれいか なる大きさの範囲において起こるかの判断が重要であろ う。つぎに評価法の意味が重要なことはいうまでもな い。それとともに，油脂の性状とドーあるいはバッター (生種)，すなわち連続相の性状とを相対的に関係づける ことによって, 複雑な現象がより整理されるのではない かと期待される。

\section{(昭和 44 年 9 月 24 日受理) \\ 文 \\ 献}

1) D. Swarn, Bailay's Iudustrial Oil and Fat Products IIIed. (1964) Interscience Publisher

2) S.A. Matz, Food Texture, 143 (1962) The Avi Publishing Co., Inc.

3) C.E. Davis, Ind. Eng. Chem., 13, 797 (1021)

4) C.H. Bailey, Cereal Chem., 11, 160 (1934)

5) W. Platt, R.S. Fleming, Ind. Eng. Chem., 15, 390 (1923)

6) W.D. Harkins et al., J. Am. Chem. Soc., 39, 354, 541 (1917)

7) I. Langmuir, J. Am. Chem. Soc., 39, 1848 (1917)

8）寺田, 吉田, 栄養と食糧, 13, 221 (1960)
9) G.T. Carlin, Bakers Digest, 21, 78 (1947)

10) G.H. Brother, H.S. Olcott, Bakers Digest, 21, 97 (1947)

11) H.S. Olcott, D.K. Mecham, Cereal Chem., 24, 407 (1947)

12) R.R. Baldwin et al., Cereal Science Today, 8, 273 (1963)

13) E.W. Cole et al., Cereal Chem., 37, 109 (1960)

14) J.C. Grosskreutz, Cereal Chem., 38, 336 (1961)

15) D. Chapman, Lipids, 4, 251 (1969)

16) R.L. Glass, Cereal Science Today, 5, 60 (1960); なお, 寺田, 総説, 油化学, 12, 450 (1963)

17) A. Schulerud, Brot u. Gebäck, 11, 240 (1957)

18) C. Aranyi, E.J. Hawrylewicz, Cereal Chem., 45, 500 (1968)

19) J.B.M. Coppock, S.J. Conford, Soc. Chem. Ind. Monograph, 7, 64 (1960)

20) 小林, 竹林, 家政学雑誌, 19, 269 (1968)

21) J. Fisher Cawood, Ind. Eng. Chem., 26, 968 (1934)

22) A.W. Harvey, Ind. Eng. Chem., 29, 1154 (1937)

23) F.J.H. Ottaway et al., J. Sci. Food Agric., 9, 115 (1958)

24) R.H. Mathews, E.H. Dawson, Cereal Chem., 40, 291 (1963)

25）松元, 中村, 新野, 家政学雑誌, 9, 14 (1958)： 松元, 油化学, 17，657 (1968)

26) B. Lowe, "Experimental Cookery", 4th ed. (1955) John Wiley \& Sons, Inc.

27) 竹林, 福井大学学芸学部紀要, 2, 10-3 集 (1960)

28) 中沢, 島田, 梅沢, 油化学, 5, 89 (1956)

29) A.J. Haighton, J. Am. Oil Chemists' Soc., 36, 345 (1959)

30) 今村, 新谷, 丸山, 松本, 油化学, 18, 16 (1969)

31) P. S $\phi$ ltoft "On the Consistency of Hardened Fats", (1947)

32) S.J. Loska Jr, E. Jaska, J. Am. Oil Chemists' Soc., 34, 495 (1957) 